\title{
Partial inhibition of human neutrophil activation by FK-506 at supratherapeutic concentrations
}

\author{
Katharina Wenzel-Seifert and Roland Seifert \\ Institut für Pharmakologie, Freie Universität Berlin, Thielallee 69-73, W-1000 Berlin 33, Germany
}

Received August 27, 1992/Accepted March 17, 1993

Summary. The macrolide, FK-506, is a potent and effective inhibitor of lymphocyte activation. We studied the effects of FK-506 on human neutrophil activation induced by chemoattractants and by various substances which circumvent receptor stimulation. After preincubation for $5 \mathrm{~min}$ at $37^{\circ} \mathrm{C}$, FK-506 $(1 \mu \mathrm{M})$ inhibited $N$-formyl- $L$-methionyl- $L$-leucyl- $L$-phenylalanine (fMet-LeuPhe)- or platelet-activating factor-induced superoxide production in neutrophils by about $30 \%$. At therapeutic concentrations $(0.1-1 \mathrm{nM})$ FK-506 was ineffective. FK-506 did not inhibit exocytosis and rises in cytosolic $\mathrm{Ca}^{2+}$ concentration $\left[\mathrm{Ca}^{2+}\right]_{i}$ mediated by these stimuli, and it did not at all inhibit neutrophil activation induced by $\mathrm{C} 5 \mathrm{a}$, leukotriene $\mathrm{B}_{4}$ and $4 \beta$-phorbol 12-myristate 13-acetate. FK-506 $(1 \mu \mathrm{M})$ inhibited A 23187-induced exocytosis by about $35 \%$, but A23187-induced superoxide production was unaffected. After preincubation for $5 \mathrm{~min}$ at $37^{\circ} \mathrm{C}$, FK-506 inhibited fMet-Leu-Phe-induced superoxide production in dibutyryl cAMP-differentiated HL-60 cells by about $20 \%$; preincubation with the drug for $24 \mathrm{~h}$ did not result in inhibition of superoxide production. FK-506 did not inhibit agonist-binding to formyl peptide receptors and fMet-Leu-Phe-stimulated GTP hydrolysis of heterotrimeric regulatory guanine nucleotidebinding proteins (G-proteins) in membranes from dibutyryl cAMP-differentiated HL-60 cells. FK-506 did not change steady-state and differential polarized phase fluorescence in HL-60 membranes using 1,6-diphenylhexa1,3,5-triene and 12-(9-anthroyloxy)-stearate as probes. Our results show that FK-506 at supratherapeutic concentrations partially inhibits neutrophil activation. Inhibition by FK-506 of fMet-Leu-Phe-induced superoxide production is rapid in onset and is not due to inhibition of agonist-binding to receptors, interference with G-proteins or protein kinase $C$, reduction of rises in $\left[\mathrm{Ca}^{2+}\right]_{i}$ or alteration in physical membrane state.
Key words: FK-506 - Human neutrophils - Superoxide production - Exocytosis - Cytosolic calcium

\section{Introduction}

Human neutrophils play an important role in non-specific host defense against bacterial infections (Malech and Gallin 1987). In neutrophils and differentiated HL-60 cells, receptors for platelet activating factor (PAF), complement C5a, leukotriene $\mathrm{B}_{4}$ and $N$-formyl- $L$-methionyl$L$-leucyl- $L$-phenylalanine (fMet-Leu-Phe), couple to heterotrimeric regulatory guanine nucleotide-binding proteins (G-proteins) (Rossi 1986; Sandborg and Smolen 1988; Dillon et al. 1988; Seifert and Schultz 1991). Activation of G-proteins results in phosphoinositide degradation with subsequent activation of protein kinase $C$, increase in cytosolic $\mathrm{Ca}^{2+}$ concentration $\left[\mathrm{Ca}^{2+}\right]_{i}$, activation of superoxide $\left(\mathrm{O}_{2}^{-}\right)$production and exocytosis (Rossi 1986; Sandborg and Smolen 1988; Dillon et al. 1988; Seifert and Schultz 1991).

FK-506 is an immunosuppressant macrolide from Streptomyces tsukabaensis (Kino et al. 1987). The in vivo and in vitro effects of FK-506 and cyclosporin A (CsA) are similar, although there are substantial differences in potency and chemical structure of the immunosuppressants (Sigal and Dumont 1992). Similar to CsA, FK-506 inhibits mitogenic or antigenic stimulation of Tand B-lymphocytes at early stages (Wicker et al. 1990; Chang et al. 1991; Sigal and Dumont 1992). In addition, FK-506 and CsA interfere with signal transduction pathways associated with rises in $\left[\mathrm{Ca}^{2+}\right]_{i}$ (Lin et al. 1991). However, inhibition by FK-506 and CsA of interleukin-2 synthesis is not associated with a reduction in $\left[\mathrm{Ca}^{2+}\right]_{\mathrm{i}}$ (Metcalfe 1984; Ryffel 1989; Bierer et al. 1990). The intracellular binding proteins for CsA and FK-506, cyclophilin and FK-506-binding protein (FKBP), respectively, do not share amino acid sequence homology (Siekierka et al. 1989; Harding et al. 1989), but both immunosuppressant-immunophilin-complexes inhibit the 
$\mathrm{Ca}^{2+}$-/calmodulin-dependent phophatase, calcineurin (Liu et al. 1991).

At therapeutic concentrations CsA only marginally inhibits human neutrophil activation (Janco and English 1983; Kharazmi et al. 1985; Wenzel-Seifert et al. 1991). Interestingly, FK-506 has recently been reported to be a very potent and effective inhibitor of A23187-induced exocytosis in human neutrophils (Forrest et al. 1991). Additionally, FK-506 partially inhibits interleukin- $1 \alpha$ release from human macrophages (Keicho et al. 1991) and potently inhibits mediator release from basophils and mast cells (De Paulis et al. 1991 a, b; Hultsch et al. 1991). All these findings prompted us to study in detail the effects of FK-506 on human neutrophil activation. We show here that FK-506 partially inhibits $\mathrm{O}_{2}^{-}$production and exocytosis at supratherapeutic concentrations.

\section{Materials and methods}

Materials. FK-506 was kindly provided by Fujisawa Pharmaceutical Co., Ltd. (Osaka, Japan). Stock solutions of FK-506 (1 mM) were prepared in dimethyl sulfoxide and were stored in polypropylene tubes at $-20^{\circ} \mathrm{C}$ under light protection for up to two months. Dilutions of FK-506 were made immediately prior to experiments. The final concentration of dimethyl sulfoxide in all experiments was adjusted to $0.1 \%$ (v/v). 12-(9-Anthroyloxy)-stearate (12-AS) was obtained from Molecular Probes (Junction City, Ore., USA); 1,6-diphenylhexa-1,3,5-triene (DPH) was from EGA Chemie (Steinheim, FRG). Stock solutions of DPH $(2 \mathrm{mM})$ were prepared in tetrahydrofurane and were kept at $25^{\circ} \mathrm{C}$. Stock solutions of 12-AS $(1 \mathrm{mM})$ were prepared in $80 \%$ ethanol $(\mathrm{v} / \mathrm{v})$ and were kept at $-20^{\circ} \mathrm{C}$. Sources of other materials have been described elsewhere (Seifert et al. 1989a, b, 1992; Wenzel-Seifert and Seifert 1990; Wenzel-Seifert et al. 1991).

Isolation of human neutrophils. Neutrophils were obtained from 12 caucasian healthy volunteers (six males and six females) approximately $2 \mathrm{~h}$ after a continental breakfast. Volunteers had taken no drugs for at least three weeks. The age of volunteers ranged from $28-40$ years; six of them were smokers. Isolation of neutrophils was performed as described (Seifert et al. 1989a). Cell preparations consisted of $>95 \%$ viable neutrophils as revealed by trypan blue dye exclusion and Pappenheim-stained smears.

Assay for $\mathrm{O}_{2}^{-}$production. $\mathrm{O}_{2}^{-}$production was monitored at $550 \mathrm{~nm}$ by continuous measurement of ferricytochrome $\mathrm{C}$ reduction inhibitable by superoxide dismutase, using an Uvikon 810 dual beam spectrophotometer (Kontron, Eching, FRG) (Seifert et al. 1989a). Reaction mixtures $(0.5 \mathrm{ml})$ contained $100 \mu \mathrm{M}$ ferricytochrome $\mathrm{C}$ and a buffer consisting of (mM) $138 \mathrm{NaCl}, 6 \mathrm{KCl}, 1 \mathrm{MgCl}_{2}, 1 \mathrm{CaCl}_{2}, 5.5$ glucose and 20 Hepes/NaOH, pH 7.4. Neutrophils $\left(1.0-2.0 \times 10^{6}\right.$ cells $)$ or dibutyryl cAMP-differentiated HL-60 cells $\left(2.5 \times 10^{6}\right.$ cells) were suspended in the solution described above and were incubated for $5 \mathrm{~min}$ at $37^{\circ} \mathrm{C}$ in the presence of FK-506 or solvent. $\mathrm{O}_{2}^{-}$production was initiated by the addition of stimuli.

Assay for $\beta$-glucuronidase and lysozyme release. Exocytosis was assessed as described (Seifert et al. $1989 \mathrm{~b}$; Wenzel-Seifert and Seifert 1990; Wenzel-Seifert et al. 1991). In one set of experiments, neutrophils $\left(4.0-5.0 \times 10^{6}\right.$ cells) were incubated for $5 \mathrm{~min}$ at $37^{\circ} \mathrm{C}$ in the buffer $(0.5 \mathrm{ml})$ described above supplemented with cytochalasin B $(5 \mu \mathrm{g} / \mathrm{ml})$ in the presence of FK-506 or solvent. Thereafter, stimuli were added to cells. In another set of experiments, neutrophils (4.0-5.0 $10^{6}$ cells) were incubated for $25 \mathrm{~min}$ at $20^{\circ} \mathrm{C}$ in the buffer $(0.5 \mathrm{ml})$ described above not supplemented with cytochalasin B, in the presence of FK-506 or solvent. Thereafter, cells were incubated for additional $5 \mathrm{~min}$ at $37^{\circ} \mathrm{C}$ in the presence of FK-506 or solvent plus cytochalasin B $(5 \mu \mathrm{g} / \mathrm{ml})$. Subsequently, stimuli were added to cells. Reactions were terminated after
$10 \mathrm{~min}$ by rapid cooling to $4^{\circ} \mathrm{C}$. Reaction mixtures were centrifuged for $10 \mathrm{~min}$ at $1000 \times \mathrm{g}$. The determinations of the activities of $\beta$ glucuronidase, lysozyme and lactate dehydrogenase of the supernatant fluids of reaction mixtures and of cell lysates were performed as described (Seifert et al. 1989b; Wenzel-Seifert and Seifert 1990; WenzelSeifert et al. 1991). Basal $\beta$-glucuronidase, lysozyme and lactate dehydrogenase release amounted to less than $5 \%$ of cellular content (data not shown).

Measurement of $\left[\mathrm{Ca}^{2+}\right]_{i} \cdot\left[\mathrm{Ca}^{2+}\right]_{\mathrm{i}}$ was determined using the fluorescent dye, Fura-2, as described (Wenzel-Seifert and Seifert 1990). Neutrophils were suspended at $5 \times 10^{6}$ cells $/ \mathrm{ml}$ in a buffer consisting of $(\mathrm{mM})$ $138 \mathrm{NaCl}, \quad 6 \mathrm{KCl}, \quad 1 \mathrm{MgSO}_{4}, \quad 1.1 \mathrm{CaCl}_{2}, \quad 0.1 \mathrm{EGTA}, \quad 1 \mathrm{Na}_{2} \mathrm{HPO}_{4}$, $5 \mathrm{NaHCO}_{3}, 5.5$ glucose, 20 Hepes/ $\mathrm{NaOH}$, pH 7.4, supplemented with bovine serum albumin $(0.1 \%$, w/v). Cells were incubated for $1 \mathrm{~h}$ at $37^{\circ} \mathrm{C}$ in the presence of Fura- 2 acetoxymethylester $(4 \mu \mathrm{M})$. Subsequently, cells were diluted with the above buffer to a final concentration of $0.5 \times 10^{6} \mathrm{cells} / \mathrm{ml}$ and were centrifuged for $10 \mathrm{~min}$ at $250 \times \mathrm{g}$ at $20^{\circ} \mathrm{C}$. Cells were suspended at $2.5 \times 10^{6} \mathrm{cells} / \mathrm{ml}$ in the above buffer and were kept at $20^{\circ} \mathrm{C}$ until measurement of $\left[\mathrm{Ca}^{2+}\right]_{\mathrm{i}}$. Fluorescence of neutrophils $\left(2.5 \times 10^{6}\right.$ cells in $\left.2 \mathrm{ml}\right)$ was determined at $37^{\circ} \mathrm{C}$ under constant stirring at $10^{3} \mathrm{rpm}$ using a Ratio II spectrofluorometer (Aminco, Silver Spring, Md., USA). Cells were incubated for $5 \mathrm{~min}$ in the presence of FK-506 or solvent prior to the addition of stimuli. The excitation and emission wavelengths were 340 and $500 \mathrm{~nm}$, respectively.

Cell culture and membrane preparation. HL-60 cells were cultured in suspension culture at $37^{\circ} \mathrm{C}$ and were differentiated towards neutrophillike cells upon incubation with dibutyryl cAMP $(0.2 \mathrm{mM})$ for $48 \mathrm{~h}$ (Seifert et al. 1989a; Wenzel-Seifert and Seifert 1990). In some experiments, FK-506 or solvent were added to cultures $24 \mathrm{~h}$ prior to experiments. HL60 membranes were prepared as described (Seifert and Schultz 1987).

Steady-state and differential polarized phase fluorometry. DPH and 12-AS were added from stock solutions to fluorometry buffer consisting of (mM) 100 mannitol, 10 Hepes/Tris, pH 7.4, and were stirred at $25^{\circ} \mathrm{C}$ for $1 \mathrm{~h}$ and $5 \mathrm{~min}$, respectively, to remove solvent. HL-60 membranes were suspended in these solutions to give final probe concentrations of $1 \mu \mathrm{M}$ (DPH) and $2 \mu \mathrm{M}(12-\mathrm{AS})$; these mixtures were incubated in the dark for $30 \mathrm{~min}$ at $37^{\circ} \mathrm{C}$. Membranes were centrifuged for $20 \mathrm{~min}$ at $48000 \times \mathrm{g}$ at $4^{\circ} \mathrm{C}$ and were resuspended in fluorometry buffer at $0.15 \mathrm{mg}$ of protein $/ \mathrm{ml}$. Membranes were incubated for $10 \mathrm{~min}$ at $25^{\circ} \mathrm{C}$ in the presence of FK-506 or solvent. Fluorescence measurements were performed at $25^{\circ} \mathrm{C}$ in a SLM 4800 spectrofluorometer (SLM Instruments, Urbana, Ill. USA) equipped with a thermostated cuvette holder. Steady state-anisotropy was measured on the T formate with $360 \mathrm{~nm}$ (DPH) and $365 \mathrm{~nm}$ (12-AS) as excitation wavelengths. Emission light was filtered through KV-418 filters (Schott, Mainz, FRG). Fluorescence lifetimes were measured at $18 \mathrm{MHz}$ by the phase modulation technique relative to a glycogen scatter solution (Spencer and Weber 1969). Differential tangent was measured by differential polarized phase fluorometry at $18 \mathrm{MHz}$ (Lakowicz et al. 1979). Rotational correlation time and limiting anisotropy were calculated from steady-state anisotropy, phase lifetime, differential tangent and $r_{0}$, i.e. the anisotropy in the absence of motion (Lakowicz et al. 1979). $\mathrm{R}_{0}$ values of 0.390 (DPH) (Lakowicz et al. 1979) and 0.285 (12-AS) (Schachter and Shinitzky 1977) were used for calculations.

fMet-Leu- $\left.P^{3} H\right] P$ he binding assay. fMet-Leu- $\left[{ }^{3} \mathrm{H}\right] \mathrm{Phe}$ binding was performed as described (Wenzel-Seifert et al. 1991). Reaction mixtures $(100 \mu \mathrm{l})$ contained $40 \mu \mathrm{g}$ of membrane protein from dibutyryl cAMPdifferentiated HL-60 cells, bovine serum albumin $(0.2 \%$, w/v), $50 \mathrm{mM}$ Tris/ $\mathrm{HCl}, \mathrm{pH} 7.3,1 \mathrm{mM}$ EDTA and $5 \mathrm{mM} \mathrm{MgCl}_{2}$ in the presence of FK-506 or solvent. Incubations were conducted for $30 \mathrm{~min}$ at $25^{\circ} \mathrm{C}$ and were initiated by the addition of $3 \mathrm{nM}$ fMet-Leu- $\left[{ }^{3} \mathrm{H}\right] \mathrm{Phe}$. Reactions were terminated by rapid filtration technique. Radioactivity on dried filters was determined in a liquid scintillation counter. Unspecific binding was determined in the presence of $10 \mu \mathrm{M}$ fMet-Leu-Phe and amounted to less than $10 \%$ of total binding. 
Measurement of GTPase activity. GTPase activity was measured as described (Seifert et al. 1992). Assay mixtures $(100 \mu \mathrm{l})$ contained membranes from HL 60 cells $\left(7.0 \mu \mathrm{g}\right.$ of protein/tube), $0.5 \mu \mathrm{M}\left[\gamma_{-}{ }^{32} \mathrm{P}\right] \mathrm{GTP}$ $(0.1 \mu \mathrm{Ci} /$ tube $), 0.5 \mathrm{mM} \mathrm{MgCl} 2,0.1 \mathrm{mM}$ EGTA, $0.1 \mathrm{mM} \mathrm{ATP,} 1 \mathrm{mM}$ adenosine $5^{\prime}$ - $[\beta, \gamma$-imido]-triphosphate, $5 \mathrm{mM}$ creatine phosphate, $40 \mu \mathrm{g}$ of creatine kinase, $1 \mathrm{mM}$ dithiothreitol and $0.2 \%(\mathrm{w} / \mathrm{v})$ bovine serum albumin in $50 \mathrm{mM}$ triethanolamine/ $\mathrm{HCl}, \mathrm{pH} 7.4$. Reaction mixtures were preincubated for $10 \mathrm{~min}$ at $25^{\circ} \mathrm{C}$ with FK-506 or solvent. Thereafter, fMet-Leu-Phe or $\mathrm{H}_{2} \mathrm{O}$ were added. After additional $10 \mathrm{~min}$ at $25^{\circ} \mathrm{C}$, reactions were initiated by the addition of $\left[\gamma_{-}^{32} \mathrm{P}\right]$ GTP and were conducted for $15 \mathrm{~min}$. Low-affinity GTPase activity was determined in the presence of GTP $(50 \mu \mathrm{M})$ and amounted to $<5 \%$ of total GTPase activity.

Miscellaneous. Protein was determined according to Lowry et al. (1951). The effects of FK-506 were statistically assessed using the Wilcoxon test.

\section{Results}

First, the effects of FK-506 on cell integrity were studied. FK-506 up to $1 \mu \mathrm{M}$ did not cause damage of neutrophils and HL-60 cells as revealed by lactate dehydrogenase release and trypan blue dye exclusion (data not shown).

The effect of FK-506 at various concentrations on $\mathrm{O}_{2}^{-}$production induced by fMet-Leu-Phe $(50 \mathrm{nM})$ is shown in Fig. 1. FK-506 above 100 nM inhibited the absolute amount and maximum rate of $\mathrm{O}_{2}^{-}$production by up to $35 \%$. At lower concentrations, FK-506 was ineffective.

The effects of FK-506 $(1 \mu \mathrm{M})$ on $\mathrm{O}_{2}^{-}$production and on rises in $\left[\mathrm{Ca}^{2+}\right]_{\mathrm{i}}$ induced by various stimuli were studied. fMet-Leu-Phe activated $\mathrm{O}_{2}^{-}$production with an $\mathrm{EC}_{50}$ of $45 \mathrm{nM}$ and a maximum at $300 \mathrm{nM}$ (Fig. 2). FK-506 reduced $\mathrm{O}_{2}^{-}$production by about $30 \%$ at all fMet-Leu-Phe concentrations employed, and it did not substantially increase the $\mathrm{EC}_{50}$. fMet-Leu-Phe increased $\left[\mathrm{Ca}^{2+}\right]_{\mathrm{i}}$ with an $\mathrm{EC}_{50}$ of $0.4 \mathrm{nM}$ and a maximum at $30 \mathrm{nM}$ (see Fig. 2); FK-506 was without effect on rises in

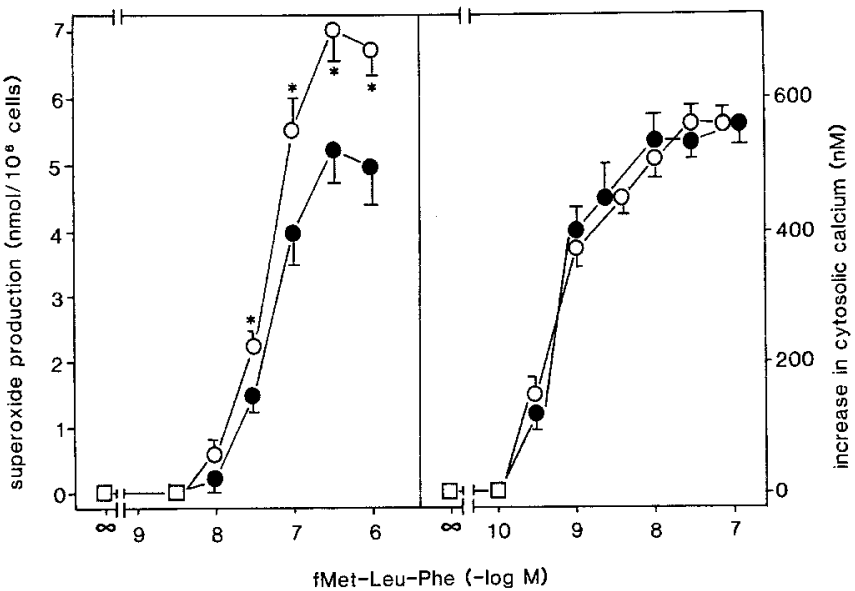

Fig. 2. Effect of FK-506 on concentration-response functions to fMetLeu-Phe-induced $\mathrm{O}_{2}^{-}$production and rises in $\left[\mathrm{Ca}^{2+}\right]_{\mathrm{i}}$ in human neutrophils. FK-506 $(1 \mu \mathrm{M})(\bullet)$ or solvent (control) $(O)$ were added to reaction mixtures $5 \mathrm{~min}$ prior to fMet-Leu-Phe at various concentrations. Open squares show that fMet-Leu-Phe at the indicated concentrations did not activate $\mathrm{O}_{2}^{-}$production or increase $\left[\mathrm{Ca}^{2+}\right]_{\mathrm{i}}$. Data shown are the means \pm SEM of assay triplicates of four experiments carried out with neutrophils from different donors. Comparison of the effect of FK-506 versus control, ${ }^{*} P<0.05$

$\left[\mathrm{Ca}^{2+}\right]_{\mathrm{i}}$. PAF activated $\mathrm{O}_{2}^{-}$production and increased $\left[\mathrm{Ca}^{2+}\right]_{\mathrm{i}}$ with $\mathrm{EC}_{50}$ values of $300 \mathrm{nM}$ and $5 \mathrm{nM}$, respectively (Fig. 3). Similar to fMet-Leu-Phe, FK-506 inhibited PAF-induced $\mathrm{O}_{2}^{-}$production by about $30 \%$, but it did not affect rises in $\left[\mathrm{Ca}^{2+}\right]_{\mathrm{i}}$. FK-506 did not inhibit $\mathrm{O}_{2}^{-}$ production induced by $\mathrm{C} 5 \mathrm{a}(1$ and $10 \mathrm{nM})$, leukotriene $\mathrm{B}_{4}(1 \mu \mathrm{M}), \mathrm{A} 23187(10 \mu \mathrm{M})$ and $4 \beta$-phorbol 12-myristate 13 -acetate (PMA) $(10,30$ and $100 \mathrm{ng} / \mathrm{ml})$ and increases in $\left[\mathrm{Ca}^{2+}\right]_{\mathrm{i}}$ induced by C5a $(0.01-3 \mathrm{nM})$ and leukotriene $\mathrm{B}_{4}$ $(0.3-100 \mathrm{nM})$ (data not shown). FK-506 by itself did not induce a rise in $\left[\mathrm{Ca}^{2+}\right]_{\mathrm{i}}$ and did not activate $\mathrm{O}_{2}^{-}$production (data not shown).

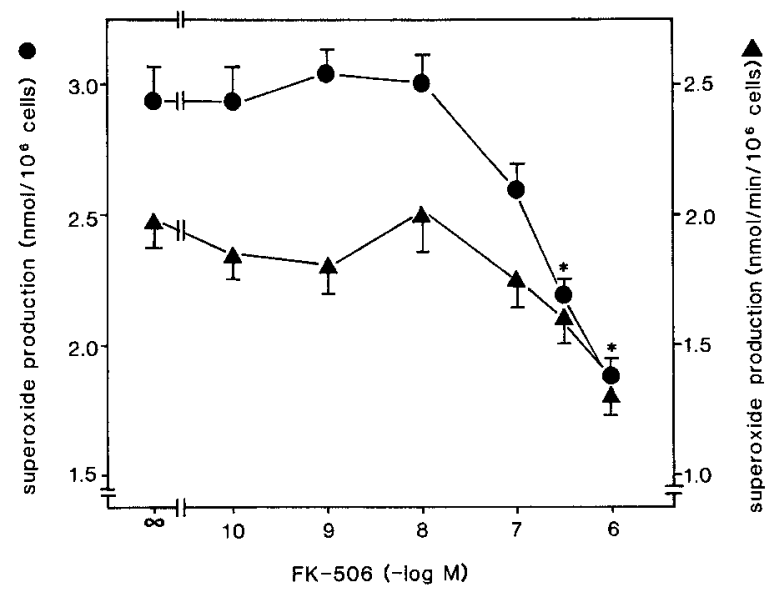

Fig. 1. Concentration-response function to FK-506 of fMet-Leu-Phe-induced $\mathrm{O}_{2}^{-}$production in human neutrophils. The effect of FK-506 on the absolute amount and maximum rate of $\mathrm{O}_{2}^{-}$production induced by fMet-Leu-Phe $(50 \mathrm{nM})$ was studied. FK-506 or solvent (control) were added to reaction mixtures $5 \mathrm{~min}$ prior to fMet-Leu-Phe. Data shown are the means \pm SEM of assay triplicates of five experiments carried out with neutrophils from different donors. Comparison of the effect of FK-506 versus control, ${ }^{*} P<0.05$

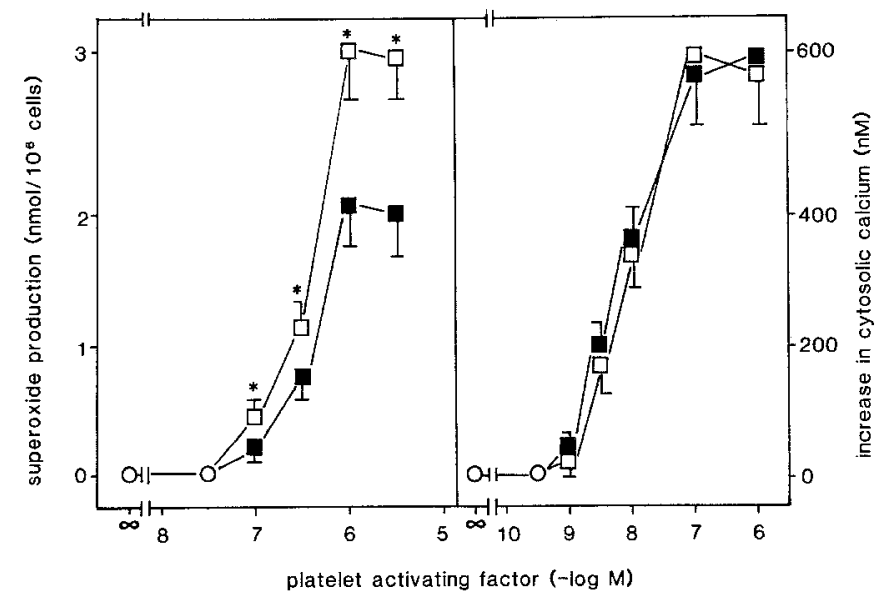

Fig. 3. Effect of FK-506 on concentration-response functions to PAF-induced $\mathrm{O}_{2}^{-}$production and rises in $\left[\mathrm{Ca}^{2+}\right]_{\mathrm{i}}$ in human neutrophils. FK-506 $(1 \mu \mathrm{M})(\boldsymbol{\square})$ or solvent (control) $(\square)$ were added to reaction mixtures $5 \mathrm{~min}$ prior to PAF at various concentrations. Open circles show that $\mathrm{PAF}$ at the indicated concentrations did not activate $\mathrm{O}_{2}^{-}$production or increase $\left[\mathrm{Ca}^{2+}\right]_{\mathrm{i}}$. Data shown are the means \pm SEM of assay triplicates of five experiments carried out with neutrophils from different donors. Comparison of the effect of FK-506 versus control, $* P<0.05$ 
Table 1. Effect of FK-506 on $\beta$-glucuronidase and lysozyme release in human neutrophils

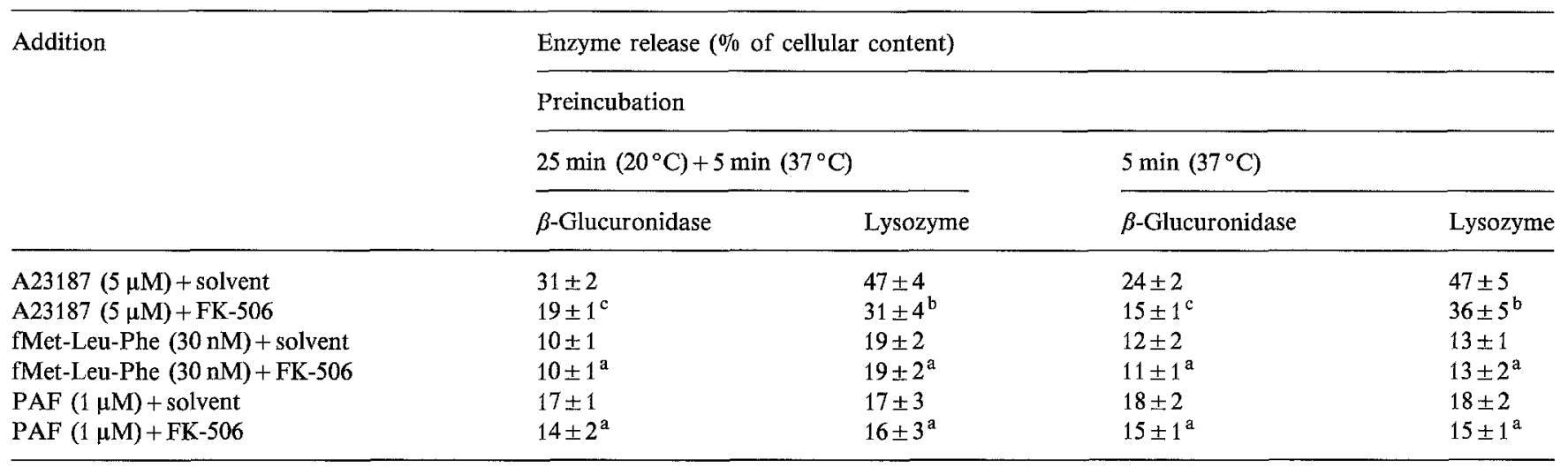

Neutrophils were preincubated with FK-506 $(1 \mu \mathrm{M})$ or solvent (control) under various conditions. Release of $\beta$-glucuronidase and lysozyme induced by various stimuli was assessed. Data shown are the means \pm SEM of assay triplicates of four experiments carried out with neutrophils from different donors

Comparison of the effect of FK-506 versus control

${ }^{a}$ Not significant

b $P<0.05$

${ }^{\mathrm{c}} P<0.01$

Table 2. Effect of FK-506 on $\mathrm{O}_{2}^{-}$production in dibutyryl cAMP-differentiated HL- 60 cells

\begin{tabular}{lll}
\hline Addition & \multicolumn{2}{l}{$\mathrm{O}_{2}^{-}$production (nmol $/ 10^{6}$ cells) } \\
\cline { 2 - 3 } & Preincubation & $24 \mathrm{~h}\left(37^{\circ} \mathrm{C}\right)$ \\
\cline { 2 - 3 } & $5 \min \left(37^{\circ} \mathrm{C}\right)$ & $2.0 \pm 0.2$ \\
Solvent & $2.1 \pm 0.2^{\circ}$ & $2.2 \pm 0.2^{\mathrm{a}}$ \\
\hline
\end{tabular}

In one set of experiments, HL-60 cells were harvested and preincubated for $5 \mathrm{~min}$ with FK-506 $(1 \mu \mathrm{M})$ or solvent (control) prior to the addition of fMet-Leu-Phe $(1 \mu \mathrm{M})$. In another set of experiments, FK-506 $(1 \mu \mathrm{M})$ or solvent (control) were added to cell cultures $24 \mathrm{~h}$ prior to experiments. Subsequently, cells were harvested and $\mathrm{O}_{2}^{-}$production induced by fMet-Leu-Phe $(1 \mu \mathrm{M})$ was assessed. Data shown are the means \pm SEM of assay triplicates of four experiments with different preparations of HL-60 cells

Comparison of the effect of FK-506 versus control

${ }^{a}$ Not significant

${ }^{\mathrm{b}} P<0.05$

The effects of FK-506 on exocytosis are shown in Table 1. FK-506 $(1 \mu \mathrm{M})$ inhibited A23187-induced $\beta$ glucuronidase and lysozyme release by $30-40 \%$, regardless of whether cells were incubated with the drug for $25 \mathrm{~min}$ at $20^{\circ} \mathrm{C}$ plus $5 \mathrm{~min}$ at $37^{\circ} \mathrm{C}$ or only for $5 \mathrm{~min}$ at $37^{\circ} \mathrm{C}$. FK-506 did not inhibit fMet-Leu-Phe- and PAFF-induced exocytosis. FK-506 per se did not activate exocytosis (data not shown).

Modulation by FK-506 of $\mathrm{O}_{2}^{-}$production in dibutyryl cAMP-differentiated HL-60 cells is shown in Table 2. After preincubation for $5 \mathrm{~min}$ at $37^{\circ} \mathrm{C}$ FK-506 inhibited fMet-Leu-Phe-induced $\mathrm{O}_{2}^{-}$production by about $20 \%$. By comparison, fMet-Leu-Phe-induced $\mathrm{O}_{2}^{-}$production was not altered in cells preincubated with FK-506 for $24 \mathrm{~h}$ at $37^{\circ} \mathrm{C}$.

The effect of FK-506 on binding of fMetLeu- $\left[{ }^{3} \mathrm{H}\right] \mathrm{Ph}$ ( $(3 \mathrm{nM})$ to formyl peptide receptors in membranes from dibutyryl cAMP-differentiated HL-60 cells was investigated. Agonist-binding in control membranes was $568 \pm 27 \mathrm{fmol} / \mathrm{mg}$ protein. FK-506 $(1 \mu \mathrm{M})$ did not alter agonist-binding to formyl peptide receptors $(569 \pm 24 \mathrm{fmol} / \mathrm{mg}$ protein).

Modulation by FK-506 of high-affinity GTPase activity in membranes from dibutyryl cAMP-differentiated HL-60 cells was studied. Basal GTP hydrolysis was $17.1 \pm 1.5 \mathrm{pmol} \quad \mathrm{P}_{\mathrm{i}} / \mathrm{mg}$ protein $/ \mathrm{min}$. fMet-Leu-Phe $(0.3 \mu \mathrm{M})$ stimulated GTP hydrolysis by $80 \%$. FK-506 $(1 \mu \mathrm{M})$ showed no effect on basal and fMetLeu-Phe-stimulated GTP hydrolysis (data not shown).

Finally, the effect of FK-506 on physical state of HL-60 membranes was studied. Steady-state anisotropy in control membranes was $0.2109 \pm 0.0033$ with DPH as probe. Phase lifetime of DPH was $9.47 \pm 0.07 \mathrm{~ns}$. Limiting anisotropy was $0.180 \pm 0.002$ and rotational correlation time was $1.62 \pm 0.11 \mathrm{~ns}$. FK-506 $(1 \mu \mathrm{M})$ had no effect on these parameters (data not shown). Steady-state anisotropy and phase lifetime of 12-AS in control membranes were $0.0849 \pm 0.0015$ and $11.12 \pm 0.10 \mathrm{~ns}$, respectively; FK-506 $(1 \mu \mathrm{M})$ showed no effect on these parameters. FK-506 did not change limiting anisotropy and rotational correlation time of 12-AS in HL-60 membranes (data not shown).

\section{Discussion}

We found that FK-506 partially inhibited fMet-Leu-Pheand PAF-induced $\mathrm{O}_{2}^{-}$production and A23187-induced exocytosis in human neutrophils at a supratherapeutic concentration $(1 \mu \mathrm{M})$ (see Figs. 2 and 3 and Table 1) (Starzl et al. 1989). Additionally, FK-506 $(1 \mu \mathrm{M})$ slightly inhibited fMet-Leu-Phe-induced $\mathrm{O}_{2}^{-}$production in differentiated HL-60 cells (see Table 2 ). These findings prompted us to study the effects of FK-506 at therapeutic concentrations on fMet-Leu-Phe-induced $\mathrm{O}_{2}^{-}$production in human neutrophils as fMet-Leu-Phe is assumed to play a key role in neutrophil activation in bacterial infec- 
tions (see Fig. 1) (Rossi 1986; Sandborg and Smolen 1988; Seifert and Schultz 1991). However, at therapeutic concentrations (0.1-1 nM) (Starzl et al. 1989), FK-506 did not inhibit $\mathrm{O}_{2}^{-}$production induced by fMet-Leu-Phe (see Fig. 1). Additionally, FK-506 was without effect on $\mathrm{O}_{2}^{-}$formation induced by leukotriene $\mathrm{B}_{4}$ and $\mathrm{C}^{5} \mathrm{a}$, two other physiologically relevant chemoattractants (Rossi 1986; Sandborg and Smolen 1988; Seifert and Schultz 1991). Furthermore, FK-506 did not at all affect exocytosis induced by fMet-Leu-Phe and PAF (see Table 1). These data suggest that the only partial inhibition of neutrophil activation by FK-506 at supratherapeutic concentrations is without clinical relevance and that FK-506 at therapeutic concentrations is unlikely to impair the non-specific defense system substantially.

The effects of FK-506 on neutrophil activation showed some similarities with the corresponding effects of CsA. The effectiveness of CsA and FK-506 $(1 \mu \mathrm{M}$ each) to inhibit fMet-Leu-Phe-induced $\mathrm{O}_{2}^{-}$production is similar (see Figs. 1 and 2) (Wenzel-Seifert et al. 1991). Like CsA, FK-506 did not inhibit fMet-Leu-Phe- and PAF-induced exocytosis and rises in $\left[\mathrm{Ca}^{2+}\right]_{\mathrm{i}}$ (see Figs. 2 and 3 and Table 1) (Wenzel-Seifert et al. 1991). Similar to CsA, FK-506 did not interfere with agonist-binding to formyl peptide receptors (Wenzel-Seifert et al. 1991). However, unlike CsA, FK-506 partially inhibited PAF-induced $\mathrm{O}_{2}^{-}$production (see Fig. 3) (Wenzel-Seifert et al. 1991). These data suggest that FK-506 and CsA inhibit neutrophil activation through related but not identical mechanisms.

FKBP is ubiquitously distributed in eukaryotic cells (Siekierka et al. 1989). In human lymphocytes, the potency of FK-506 in functional assays ( $\mathrm{IC}_{50}$ approximately $0.1 \mathrm{nM}$ ) is in accordance with the affinity of FK-506 to FKBP $\left(\mathrm{K}_{\mathrm{D}}\right)$ of $0.4-0.8 \mathrm{nM}$ ) (Sigal and Dumont 1992; Siekierka et al. 1989). These data suggest that the FK-506-FKBP complex mediates the immunosuppressive effects of the drug in these cells. In addition, FK-506 inhibits activation of mast cells and basophils with $\mathrm{IC}_{50}$ values of 1-5 nM (De Paulis et al. 1991 a,b; Hultsch et al. 1991). By comparison, FK-506 at these concentrations was without effect on fMet-Leu-Phe-induced $\mathrm{O}_{2}^{-}$production, and FK-506 $(1 \mu \mathrm{M})$ showed no or only relatively small inhibitory effects on various neutrophil activation parameters (see Figs. $1-3$ and Tables 1 and 2). These data suggest that the inhibitory effects of FK-506 on neutrophil activation are not mediated by the FK-506FKBP complex. It cannot, however, be excluded that FK-506 penetrates the neutrophil plasma membrane only poorly, i.e. the drug has to be present at very high extracellular concentrations to reach sufficient concentrations in the cytosol for interaction with FKBP.

Several other possibilities have to be discussed to explain the inhibitory effects of FK-506 on human neutrophil activation. First, the failure of FK-506 to inhibit agonist-binding to formyl peptide receptors suggests that it does not act as formyl peptide receptor antagonist. Second, the lack of effect of FK-506 on high-affinity GTPase in HL-60 membranes indicates that the drug does not interfere with G-proteins. Third, FK-506 did not inhibit PMA-induced $\mathrm{O}_{2}^{-}$production suggesting that it does not act as inhibitor of protein kinase C. Fourth, the lack of effect of FK-506 on $\mathrm{O}_{2}^{-}$production induced by various stimuli implies that it does not interfere with a component of NADPH oxidase, the $\mathrm{O}_{2}^{-}$-generating enzyme system (Rossi 1986; Seifert and Schultz 1991). Similarly, the failure of FK-506 to inhibit exocytosis by various stimuli implies that it does not interfere with secretory mechanisms in an unspecific manner (see Table 1). Additionally, the lack of effect of FK-506 on fMet-Leu-Phe- and PAFinduced rises in $\left[\mathrm{Ca}^{2+}\right]_{\mathrm{i}}$ indicates that the drug does not interfere with $\mathrm{Ca}^{2+}$ mobilization and/or $\mathrm{Ca}^{2+}$ influx from the extracellular space (see Figs. 2 and 3). Furthermore, we did not observe toxic effects of FK-506 on human neutrophils. Finally, the inhibitory effects of FK-506 were evident after short-term preincubation of cells but not after long-term treatment (see Figs. 1-3 and Tables 1 and 2). Thus, FK-506 apparently does not act via inhibition of gene transcription or protein synthesis. Interestingly, inhibitory effects of FK-506 on basophil and mast cell activation are also evident after short-term preincubation (De Paulis et al. $1991 \mathrm{a}, \mathrm{b}$; Hultsch et al. 1991).

FK-506 is a very lipophilic drug (Kino et al. 1987). This fact and the supratherapeutic concentrations of FK-506 required to partially inhibit neutrophil activation (see Fig. 1) (Starzl et al. 1989) raise the question of whether the drug acts via alteration of physical membrane state. A widely employed technique for the study of physical membrane state is steady-state polarization and differential polarized phase fluorometry with DPH and 12-AS as probes. Absolute steady-state anisotropy of DPH in dibutyryl cAMP-differentiated HL-60 membranes was similar to the one in membranes from dimethyl sulfoxide-differentiated HL-60 cells, human neutrophils, lymphocytes and erythrocytes (Shinitzky and Inbar 1974; Ip and Cooper 1980; Giraud et al. 1991; Yuli et al. 1982). Limiting anisotropy reflects lipid packing order in the membrane restricting the probes' rotational motion, i.e. it is a static measure; rotational correlation time reflects mobility of the probe in the lipid environment, i.e. it is a dynamic measure (Lakowicz et al. 1979). The lack of effect of FK-506 on limiting anisotropy and rotational correlation time clearly argues against alterations in physical membrane state accounting for its partial inhibitory effects on neutrophil activation. Taken together, the mechanism of action of FK-506 in human neutrophils is still unknown.

There are some similarities and dissimilarities between the results obtained by us und by Forrest et al. (1991). In agreement with our data are their findings that FK-506 and CsA do not inhibit fMet-Leu-Phe-induced exocytosis (see Table 1) (Wenzel-Seifert et al. 1991). However, Forrest et al. (1991) reported that FK-506, after preincubation for $25 \mathrm{~min}$ at room temperature, inhibited exocytosis induced by A23187 at a maximally effective concentration $(1 \mu \mathrm{M})$ in human neutrophils with an $\mathrm{IC}_{50}$ of about $1 \mathrm{nM}$ and a maximum at $10 \mathrm{nM}$. In our hands, A23187 was maximally effective at $5 \mu \mathrm{M}$, whereas A 23187 at $1 \mu \mathrm{M}$ induced the release of only about $5 \%$ of the cellular content of $\beta$-glucuronidase release, i.e. this stimulation was too small for reliable quantitative assessment of the inhibitory effect of FK-506 (data not shown). 
Differences in the maximally effective concentrations of A 23187 for stimulation of exocytosis among various groups have been reported before (Kang et al. 1985; Becker et al. 1985; Naccache et al. 1985). In contrast to Forrest et al. (1991), we found that FK-506 as high as $1 \mu \mathrm{M}$ showed only relatively small inhibitory effects on A 23187-induced exocytosis, regardless of whether cells were preincubated with the drug for $25 \mathrm{~min}$ at $20^{\circ} \mathrm{C}$ plus $5 \mathrm{~min}$ at $37^{\circ} \mathrm{C}$ or only for $5 \mathrm{~min}$ at $37^{\circ} \mathrm{C}$ (see Table 1). Basically, the methods applied by us and by Forrest et al. (1991) (see Materials and methods) were similar. It is possible that differences in responsiveness to FK-506 of neutrophils in both studies existed. Interestingly, Kahan et al. (1991) reported on substantial variation in responsiveness to FK-506 among lymphocytes from different donors. In addition, it is known that regulation of $\mathrm{O}_{2}^{-}$ production may depend on several conditions such as sex, age, active and passive smoking, feeding state and method of cell isolation (Seifert and Schultz 1991; Lipschitz et al. 1991; Anderson et al. 1991; Uhlinger et al. 1991). With regard to the donors studied by us, however, FK-506 showed very consistent effects (see Figs. 1-3 and Table 1). Specifically, we did not observe that neutrophils of some donors were highly sensitive to inhibition by FK-506, whereas cells from other donors were insensitive. Unfortunately, Forrest et al. (1991) did not provide sufficient information on the above-mentioned factors in their volunteers. Regardless of the reason for the differences between our results and those of Forrest et al. (1991) should it be kept in mind that A23187, unlike fMetLeu-Phe, C5a, PAF and leukotriene $B_{4}$, is not a physiologically relevant stimulus (Rossi 1986; Sandborg and Smolen 1988; Seifert and Schultz 1991).

In conclusion, we have shown that FK-506 at therapeutic concentrations does not inhibit human neutrophil activation. At supratherapeutic concentrations FK-506 partially inhibits neutrophil activation through a mechanism which is rapid in onset and does not involve inhibition of agonist binding to formyl peptide receptors, interference with G-proteins or protein kinase $C$, reduction of rises in $\left[\mathrm{Ca}^{2+}\right]_{i}$ or changes in physical membrane state.

Acknowledgements. The authors are greatful to Prof. Dr. H. Ebel, Institut für Klinische Physiologie, Universitätsklinikum Steglitz, Freie Universität Berlin for supply of the SLM-spectrofluorometer and helpful advice and to Mrs. E. Glaß, Mrs. M. Christowa and Mrs. B. Papanis for expert technical assistance. This work was supported by grants of the Deutsche Forschungsgemeinschaft.

\section{References}

Anderson R, Theron AJ, Richards GA, Myers MS, Van Rensburg AJ (1991) Passive smoking by humans sensitizes circulating neutrophils. Am Rev Respir Dis 144:570-574

Becker EL, Kermode JC, Naccache PH, Yasson R, Marsh ML, Munoz JJ, Sha'afi RI (1985) The inhibition of neutrophil granule enzyme secretion and chemotaxis by pertussis toxin. J Cell Biol 100: $1641-1646$

Bierer BE, Schreiber S, Burakoff S (1990) Mechanisms of immunosuppression by FK-506. Preservation of T cell transmembrane signal transduction. Transplantation 49:1168-1170
Chang JY, Seghal SN, Bansbach CC (1991) FK-506 and rapamycin: novel pharmacological probes of the immune response. Trends Pharmacol Sci 12:218-223

De Paulis A, Cirillo R, Ciccarelli A, Condorelli M, Marone G (1991 a) FK-506, a potent novel inhibitor of the release of proinflammatory mediators from human FceRI ${ }^{+}$cells. J Immunol 146:2374-2381

De Paulis A, Cirillo R, Ciccarelli A, De Crescenzo G, Oriente A, Marone $\mathrm{G}(1991 \mathrm{~b})$ Characterization of the anti-inflammatory effect of FK-506 on human mast cells. J Immunol 147:4278-4285

Dillon SB, Verghese MW, Snyderman R (1988) Signal transduction in cells following binding of chemoattractants to membrane receptors. Virchows Arch B Cell Pathol 55:65-80

Forrest MJ, Jewell ME, Koo GC, Sigal NH (1991) FK-506 and cyclosporin A: selective inhibition of calcium ionophore-induced polymorphonuclear leukocyte degranulation. Biochem Pharmacol 42:1221-1228

Giraud F, Claret M, Bruckdorfer KR, Chailley B (1981) The effects of membrane lipid order and cholesterol on the internal and external cationic sites of the $\mathrm{Na}^{+}-\mathrm{K}^{+}$pump in erythrocytes. Biochim Biophys Acta 647:249-258

Harding MW, Galat A, Uehling DE, Schreiber SL (1989) A receptor for the immunosuppressant FK-506 is a cis-trans peptidyl-prolyl isomerase. Nature 341:758-760

Hultsch T, Albers MW, Schreiber SL, Hohman RJ (1991) Immunophilin ligands demonstrate common features of signal transduction leading to exocytosis or transcription. Proc Natl Acad Sci USA 88:6229-6233

Ip SHC, Cooper RA (1980) Decreased membrane fluidity during differentiation of human promyelocytic leukemia cells in culture. Blood $56: 227-232$

Janco RL, English D (1983) Cyclosporine and human neutrophil function. Transplantation 35:501-503

Kahan BD, Gibbons S, Tejpal N, Stepkowski SM, Chou T-C (1991) Synergistic interactions of cyclosporine and rapamycin to inhibit immune performances of normal human peripheral blood lymphocytes in vitro. Transplantation 51:232-239

Kang D, Tsuda H, Takeshige K, Shibata Y, Minakami S (1985) The role of $\mathrm{Ca}^{2+}$ and $\mathrm{Ca}^{2+}$-activated phospholipid-dependent protein kinase in degranulation of human neutrophils. $\mathbf{J}$ Biochem 98:1699-1706

Keicho N, Sawade S, Kitamura K, Yotsumoto H, Takaku F (1991) Effects of an immunosuppressant, FK-506, on Interleukin $1 \alpha$ production by human macrophages and a macrophage-like cell line, U937. Cell Immunol 132:285-294

Kharazmi A, Svenson M, Nielsen H, Birgens HS (1985) Effect of cyclosporin A on human neutrophil and monocyte function. Scand J Immunol 21:585-591

Kino T, Hatanaka H, Nishiyama M, Goto T, Okuhara M, Kohsaka M, Aoki H, Imanaka H (1987) FK-506, a novel immunosuppressant isolated from a Streptomyces. Fermentation, isolation, and physicochemical and biological characteristics. J Antibiotics 40:1249-1255

Lakowicz JR, Prendergast FG, Hogen D (1979) Differential polarized phase fluorometric investigations of diphenylhexatriene in lipid bilayers. Quantitation of hindered depolarizing rotations. Biochemistry $18: 508-519$

Lin CS, Boltz RC, Siekierka JJ, Sigal NH (1991) FK-506 and cyclosporine A inhibit highly similar signal transduction pathways in human T lymphocytes. Cell Immunol 133:269-284

Lipschitz DA, Udupa KB, Indelicato SR, Das M (1991) Effect of age on second messenger generation in neutrophils. Blood 78: $1347-1354$

Liu J, Farmer JD Jr., Lane WS, Friedman J, Weissman I, Schreiber SL (1991) Calcineurin is a common target of cyclophilin-cyclosporin A and FKBP-FK-506 complexes. Cell 66:807-815

Lowry OH, Rosebrough NJ, Farr AL, Rall RJ (1951) Protein measurement with the Folin phenol reagent. J Biol Chem 193:265-275

Malech HL, Gallin MD (1987) Neutrophils in human diseases. N Engl J Med 317:687-694

Metcalfe S (1984) Cyclosporine does not prevent cytoplasmic calcium changes associated with lymphocyte activation. Transplantation 49:798-802 
Naccache PH, Molski TFP, Borgeat P, White JR, Sha'afi RI (1985) Phorbol esters inhibit the fMet-Leu-Phe- and leukotriene $B_{4}$-stimulated calcium mobilization and enzyme secretion in rabbit neutrophils. J Biol Chem 260:2125-2131

Rossi F (1986) The $\mathrm{O}_{2}^{-}$-forming NADPH oxidase of phagocytes: nature, mechanics of activation and function. Biochim Biophys Acta 853:65-89

Ryffel B (1989) Pharmacology of cyclosporine. VI. Cellular activation: Regulation of intracellular events by cyclosporine. Pharmacol Rev $41: 407-422$

Sandborg RR, Smolen JE (1988) Biology of disease. Early biochemical events in leukocyte activation. Lab Invest 59:300-320

Schachter D, Shinitzky M (1977) Fluorescence polarization studies of rat intestinal microvillus membranes. J Clin Invest 59:536-548

Seifert, R, Schultz G (1987) Reversible activation of NADPH oxidase in membranes of HL-60-leukemic cells. Biochem Biophys Res Commun 146:1296-1302

Seifert R, Schultz G (1991) The superoxide-forming NADPH oxidase of phagocytes: An enzyme system regulated by multiple mechanisms. Rev Physiol Biochem Pharmacol 117:1-338

Seifert R, Burde R, Schultz G (1989a) Lack of effect of opioid peptides, morphine and naloxone on superoxide formation in human neutrophils and HL-60 leukemic cells. Naunyn-Schmiedeberg's Arch Pharmacol 340:101 - 106

Seifert R, Wenzel K, Eckstein F, Schultz G (1989 b) Purine and pyrimidine nucleotides potentiate activation of NADPH oxidase and degranulation by chemotactic peptides and induce aggregation of human neutrophils via G proteins. Eur J Biochem 181:277-285

Seifert R, Serke S, Huhn D, Bessler G, Hauschildt S, Metzger J, Wiesmüller K-H, Jung G (1992) Imcomplete functional differentiation of HL-60-leukemic cells by synthetic lipopeptides. Partial inhibition by pertussis toxin of enhanced superoxide formation. Eur J Biochem 203:143-151

Shinitzky M, Inbar M (1974) Difference in microviscosity induced by different cholesterol levels in the surface membrane lipid bilayer of normal lymphocytes and malignant lymphoma cells. J Mol Biol 85:603-615

Siekierka JJ, Hung SH, Poe M, Lin CS, Sigal NH (1989) A cytosolic binding protein for the immunsuppressant FK-506 has peptidyl-prolyl isomerase activity but is distinct from cyclophilin. Nature 341:755-757

Sigal NH, Dumont FJ (1992) Cyclosporin A, FK-506, and rapamycin: Pharmacologic probes of lymphocyte signal transduction. Annu Rev Immunol 10:519-560

Spencer RD, Weber G (1969) Measurements of subnanosecond fluorescence lifetimes with a cross-correlation phase fluorometer. Ann N Y Acad Sci 158:361 - 376

Starzl TE, Todo S, Fung J, Demetris AJ, Venkataramman R, Jain A (1989) FK-506 for liver, kidney and pancreas transplantation. Lancet II: $1000-1004$

Uhlinger DJ, Burnham DN, Mullins RE, Kalmar JR, Cutler CW, Arnold RR, Lambeth JD, Merrill AH Jr (1991) Functional differences in human neutrophils isolated pre- and post-prandially. FEBS Lett 286:28-32

Wenzel-Seifert K, Seifert R (1990) Nucleotide-, chemotactic peptideand phorbol ester-induced exocytosis in HL-60 leukemic cells. Immunobiology 181:298-216

Wenzel-Seifert K, Grünbaum L, Seifert R (1991) Differential inhibition of human neutrophil activation by cyclosporines $\mathrm{A}, \mathrm{D}$ and $\mathrm{H}$ : Cyclosporin $\mathrm{H}$ is a potent and effective inhibitor of formyl peptideinduced superoxide formation. J Immunol 147:1940-1946

Wicker LS, Boltz RC Jr., Matt V, Nichols EA, Peterson LB, Sigal NH (1990) Suppression of B cell activation by cyclosporine A, FK-506 and rapamycin. Eur J Immunol 20:2277-2283

Yuli I, Tomonaga A, Snyderman R (1982) Chemoattractant receptor functions in human polymorphnuclear leukocytes ard divergently altered by membrane fluidizers. Proc Natl Acad Sci USA 79: $5906-5910$ 